\title{
Occurrence of anti-Toxoplasma gondii antibodies in cattle and pigs slaughtered, State of Rio de Janeiro
}

Ocorrência de anticorpos anti-Toxoplasma gondii em bovinos e suínos abatidos, Estado do Rio de Janeiro

Daniela Martins Luciano'; Rodrigo Caldas Menezes²; Luiz Cláudio Ferreiraª

José Leonardo Nicolau'; Leandro Batista das Neves ${ }^{1}$; Raquel Martins Luciano ${ }^{3}$;

Magyda Arabia Araji Dahrougi'; Maria Regina Reis Amendoeira ${ }^{1 *}$

${ }^{1}$ Toxoplasmosis Laboratory, Instituto Oswaldo Cruz, Fundação Oswaldo Cruz - FIOCRUZ

${ }^{2}$ Laboratory for Clinical Research on Dermatozoonoses in Domestic Animals, Instituto de Pesquisa Clínica Evandro Chagas, Fundação Oswaldo Cruz - FIOCRUZ

${ }^{3}$ Autonomous veterinarian

Received March 22, 2011

Accepted June 14, 2011

\begin{abstract}
This study aimed to estimate the occurrence of anti-Toxoplasma gondii antibodies by means of the Indirect Immunufluorescent Antibody Assay (IFAT) in cattle and pigs from slaughterhouses in two municipalities in the State of Rio de Janeiro. IgG anti-T. gondii antibodies was found in 1.96\% (9/459) of the cattle and $7.64 \%(31 / 406)$ of the pigs, without any positive association $(\mathrm{p}>0.05)$ with risk factors for transmission and seropositivity. Taking the cutoff point of IFAT ${ }^{3} 1: 64$, titers of 64 and 256 were detected, suggesting chronic infection. Despite the low prevalence rates found for cattle and pigs, these indicated environmental contamination in the municipalities investigated, biosafety failures at the technified pig farm evaluated and the possibility of human and animal infection through eating raw or undercooked meat from these animals.
\end{abstract}

Keywords: Toxoplasma gondii, cattle, pigs, seroprevalence.

\section{Resumo}

Este trabalho objetivou estimar a ocorrência de anticorpos anti-Toxoplasma gondii por meio da Reação de Imunofluorescência Indireta (RIFI) em bovinos e suínos de abatedouros de dois municípios do Estado do Rio de Janeiro. Anticorpos IgG anti-T. gondii foram encontrados em 1,96\% (9/459) dos bovinos e em 7,64\% (31/406) dos suínos, sem associação positiva $(\mathrm{p}>0,05)$ em relação aos fatores de risco de transmissão e a soropositividade. Considerando-se o ponto de corte (RIFI ${ }^{3}$ 1:64), foram detectados os títulos de 64 e 256, sugestivos de infecção crônica. Apesar de baixas, as prevalências encontradas para bovinos e suínos indicaram contaminação ambiental nos municípios avaliados, falhas na biossegurança da granja tecnificada de suínos e a possibilidade de infecçáo humana e animal pela ingestáo da carne crua ou mal passada desses animais.

Palavras-chave: Toxoplasma gondii, bovinos, suínos, soroprevalência.

Toxoplasmosis is a widely distributed protozoan disease around the world, caused by Toxoplasma gondii. It affects a large variety of vertebrate animals, including mammals and birds (AMENDOEIRA et al., 1999; MILLAR et al., 2008).

Pigs become infected mainly through ingestion of oocysts that are eliminated in the feces of cats that live on farms. Cat feces contaminate animal feed, the soil and water. Pigs can also

*Corresponding author: Maria Regina Reis Amendoeira

Laboratório de Toxoplasmose, Instituto Oswaldo Cruz,

Fundação Oswaldo Cruz - FIOCRUZ, Av. Brasil, 4365, Manguinhos,

CEP 21045-900, Rio de Janeiro, RJ, Brazil

e-mail: amendoei@ioc.fiocruz.br become infected across the placenta (GAMBLE et al., 1999). Cattle become infected mainly through consumption of fodder and water contaminated with sporulated oocysts (MILLAR et al., 2008).

The seroprevalence among production animals signals the problem in rural regions, since these animals are in direct contact with the environment for long periods (BONNA et al., 2006; MURARO et al., 2010). The aim of this study was to investigate occurrences of IgG anti- $T$. gondii, using the Indirect Immunufluorescent Antibody Assay (IFAT), as described by Camargo (1964), in cattle and pigs slaughtered in two municipalities in the State of Rio de Janeiro. For this, a cross-sectional descriptive study was conducted on 865 animals from slaughterhouses certified 
by the sanitary inspection service of the State of Rio de Janeiro, using cattle from the municipality of Quissamã (22 06' 24" S and $\left.41^{\circ} 28^{\prime} 20^{\prime \prime} \mathrm{W}\right)$ and pigs from the municipality of Petrópolis $\left(22^{\circ} 30^{\prime} 18^{\prime \prime} \mathrm{S}\right.$ and $\left.43^{\circ} 10^{\prime} 44^{\prime \prime} \mathrm{W}\right)$.

The sample was estimated by means of the Epi-Info software, version 3.5.1 (CDC, 2008), based on the total population of the herd of each species in each municipality, according to data from the IBGE (2008). The reference point taken was an expected prevalence of $50 \%$, with a $95 \%$ confidence interval and absolute error of 0.05 .

After a free and informed consent statement was signed by the individuals with technical responsibility for the slaughterhouses, 459 blood samples were collected from cattle and 406 from pigs, and these were sent to the Toxoplasmosis Laboratory of IOC/Fiocruz for storage at $-20^{\circ} \mathrm{C}$. For the IFAT, the samples underwent serial fourfold dilutions down to 1:4096, and samples with titers $\geq 64$ were considered positive in cattle (DAGUER et al., 2004) and in pigs (CARLETTI et al., 2005).

For the statistical analyses, Pearson's chi-square test with Yates correction or Fisher's exact test was used. The results were considered significant when $\mathrm{p} \leq 0.05$. This study was approved by the Ethics Committee for Animal Use (CEUA), at Fiocruz, under protocol P-520/08 and license L-006/09.

The occurrence rate of $\operatorname{IgG}$ anti- $T$. gondii antibodies in the cattle was $1.96 \%$ (Table 1 ), which was similar to what was observed by Gondim et al. (1999) in Brazil (1.03\%), through using the latex agglutination test (LAT) with a cutoff point of 1:64. Other frequencies have also been described, going from 11.0 to $71.0 \%$, using methodologies like the immunoenzymatic test (ELISA) and IFAT, with the same cutoff point in the latter (MEIRELES et al., 2003; SANTOS et al., 2009). In other countries, the ranges observed (from 0 to $91.0 \%$ ) may be related to the use of different cutoff points in IFAT, i.e. 1:25 or 1:128 (MORÉ et al., 2008; SHARIF et al., 2007), or to different methodologies.

The only titer found in the cattle was 64, which corroborated the findings of Gondim et al. (1999). It has been suggested that low antibody titers would indicate chronic infection, with the presence of tissue cysts (DAGUER et al., 2004). No statistically significant differences in relation to sex were observed $(p$ Fisher $=0.10)$.

In the pigs, the occurrence rate of IgG anti- $T$. gondii antibodies was $7.64 \%$ (Table 1), which is concordant with the studies by Garcia-Vasquez et al. (1993) in Mexico (8.90\%) and Suaréz-Aranda et al. (2000) in Brazil (9.60\%), who used ELISA. In Brazil, ranges from 1.11 to 65.80\% (SOUZA, 1995; BONNA et al., 2006) and in other countries from 5.0 to $47.40 \%$ (DUBEY, 1985; GAMBLE et al., 1999) have already been described, using the methods of indirect hemagglutination (IHA), IFAT, dye test (DT) and modified agglutination test (MAT).

Variations in seroprevalence around the world may be attributed to differences in ecosystems, serological tests or cutoff points.

The serological titers found in the pigs (Table 1) suggest that chronic infection was present, and these observations were similar to those of Carletti et al. (2005). The lack of statistically significant difference $\left(\chi^{2}=1.01 ; p\right.$ Yates $\left.=0.31\right)$ in occurrences of infection due to T. gondii in relation to sex (Table 2) was also observed by Souza (1995), since both genders were exposed to the same
Table 1. Occurrences of IgG anti-T. gondii antibodies detected by means of IFAT, with the respective titers, in serum from cattle and pigs from two municipalities in the State of Rio de Janeiro, Brazil.

\begin{tabular}{lccccc}
\hline Species & $\begin{array}{c}\text { No of } \\
\text { samples } \\
\text { examined }\end{array}$ & \multicolumn{3}{c}{$\begin{array}{c}\text { No of reactive } \\
\text { samples }\end{array}$} & $\begin{array}{c}\text { 95\% confidence } \\
\text { interval }\end{array}$ \\
\cline { 2 - 5 } & Titer & No & \% & \\
\hline Cattle & 459 & 64 & 9 & 1.96 & $0.9-3.69 \%$ \\
Pigs & 406 & Total & 31 & 7.64 & $5.25-10.66 \%$ \\
& & 64 & 29 & 7.14 & \\
& & 256 & 2 & 0.49 & \\
\hline
\end{tabular}

Table 2. Occurrences of $\operatorname{IgG}$ anti-T. gondii antibodies detected by means of IFAT, according to sex, in cattle and pigs from two municipalities in the State of Rio de Janeiro, Brazil.

\begin{tabular}{lccccccc}
\hline Species & \multicolumn{5}{c}{ Sex } \\
\cline { 2 - 4 } \cline { 2 - 3 } \cline { 5 - 7 } & $\begin{array}{c}\text { No of } \\
\text { samples }\end{array}$ & $\begin{array}{c}\text { No of } \\
\text { reactive } \\
\text { samples }\end{array}$ & $\%$ & & $\begin{array}{c}\text { No of } \\
\text { samples }\end{array}$ & $\begin{array}{c}\text { No of } \\
\text { reactive } \\
\text { samples }\end{array}$ & $\%$ \\
\hline Cattle & 280 & 8 & 2.86 & 179 & 1 & 0.56 \\
Pigs & 194 & 18 & 9.28 & 212 & 13 & 6.13 \\
\hline
\end{tabular}

Cattle: $p$ Fisher $=0.10$; Pigs: $\chi^{2}=1.01, p$ Yates $=0.31$.

risk factors. The pigs' ages (from four to six months) may have contributed towards the low occurrence of antibodies, because the short time for which they remained on the farm may have diminished the likelihood of infection (CARLETTI et al., 2005). Moreover, improvements in hygiene and sanitation, use of manufactured feed, rodent control and control over access by cats may also have contributed to this (GAMBLE et al., 1999; SUARÉZ-ARANDA et al., 2000). The pigs came from a technified farm with intensive husbandry, and they consumed treated feed and drinking water. There were no reports of the presence of cats living together with the cattle and pigs evaluated.

Comparing the observed occurrences in these two species, the results corroborated the findings of Dubey (1985). Both beef and pork may contain viable cysts in the tissue, and these are sources of infection for humans if consumed raw or undercooked, as are processed meats (MILLAR et al., 2008). Factors such as susceptibility, management of husbandry, environmental contamination and the dietary habits of each species may have influenced the results. Prevention of infection in these animals is based on adopting good production practices.

\section{Acknowledgements}

To Professor Paulo Roberto Chaves da Silva, for technical assistance.

\section{References}

AMENDOEIRA, M. R. R.; COSTA, T.; SPALDING, S. M. Toxoplasma gondii Nicolle \& Manceaux, 1909 (Apicomplexa: Sarcocystidae) e a Toxoplasmose. Revista Souza Marques, v. 1, n. 1, p. 15-35, 1999. 
BONNA, I. C. F. et al. Estudo soroepidemiológico da infecção por Toxoplasma gondii em suínos e frangos, para abate, em regiáo rural do Rio de Janeiro. Revista Brasileira de Ciência Veterinária, v. 13, n. 3, p. 186-189, 2006.

CAMARGO, M. E. Improved technique of indirect immunofluorescence for serological diagnosis of toxoplasmosis. Revista do Instituto de Medicina Tropical de Sáo Paulo, v. 6, n. 3, p. 117-118, 1964.

CARLETTI, R. T. et al. Prevalência da infecção por Toxoplasma gondii em suínos abatidos no Estado do Paraná, Brasil. Semina: Ciências Agrárias, v. 26, n. 4, p. 563-568, 2005.

CENTERS FOR DISEASE CONTROL AND PREVENTION - CDC. Epi Info. 2008. Disponível em: <http://www.cdc.gov/epiinfo/ei2008. htm>. Acesso em: 20 set. 2008.

DAGUER, H. et al. Soroprevalência de anticorpos anti-Toxoplasma gondii em bovinos e funcionários de matadouros da microrregião de Pato Branco, Paraná, Brasil. Ciência Rural, v. 34, n. 4, p. 1133-1137, 2004.

DUBEY, J. P. Serologic prevalence of toxoplasmosis in cattle, sheep, goats, pigs, bison and elk in Montana. Journal of the American Veterinary Medical Association, v. 186, n. 9, p. 969-970, 1985.

GAMBLE, H. R.; BRADY, R. C.; DUBEY, J. P. Prevalence of Toxoplasma gondii infection in domestic pigs in the New England states. Veterinary Parasitology, v. 82, n. 2, p. 129-136, 1999. http://dx.doi.org/10.1016/ S0304-4017(99)00004-7

GARCIA-VASQUEZ, Z. et al. Seroprevalence of Toxoplasma gondii infection in cattle, swine and goats in four Mexican states. Preventive Veterinary Medicine, v. 17, n. 1-2, p. 127-132, 1993. http://dx.doi. org/10.1016/0167-5877(93)90061-W

GONDIM, L. F. P. et al. Serological survey of antibodies to Toxoplasma gondii in goats, sheep, cattle and water buffaloes in Bahia State, Brazil. Veterinary Parasitology, v. 82, n. 4, p. 273-276, 1999. http://dx.doi. org/10.1016/S0304-4017(99)00033-3
INSTITUTO BRASILEIRO DE GEOGRAFIA E ESTATÍSTICA IBGE. Disponível em: <http://www.ibge.gov.br/cidadesat/topwindow. htm>. Acesso em: 20 set. 2008.

MEIRELES, L. R.; GALISTEO JUNIOR , A. J.; ANDRADE JUNIOR, H. F. Serological survey of antibodies to Toxoplasma gondii in food animals from São Paulo state, Brazil. Brazilian Journal of Veterinary Research and Animal Science, v. 40, n. 4, p. 267-271, 2003. http://dx.doi.org/10.1590/S1413-95962003000400005

MILLAR, P. R. et al. A importância dos animais de produção na infecção por Toxoplasma gondii no Brasil. Semina: Ciências Agrárias, v. 29, n. 3 , p. 693-706, 2008.

MORÉ, G. et al. Diagnosis of Sarcocystis cruzi, Neospora caninum, and Toxoplasma gondii infections in cattle. Parasitology Research, v. 102, n. 4, p. 671-675, 2008.

MURARO, L. S. et al. Seroprevalence of Toxoplasma gondii infection in swine matrices in Nova Mutum and Diamantino, Mato Grosso, Brazil. Revista Brasileira de Parasitologia Veterinária, v. 19, n. 4, p. 254-255, 2010.

SANTOS, T. R. et al. Prevalence of anti-Toxoplasma gondii antibodies in dairy cattle, dogs and humans from the Jauru micro-region, Mato Grosso state, Brazil. Veterinary Parasitology, v. 161, n. 3-4, p. 324-326, 2009. PMid:19232473. http://dx.doi.org/10.1016/j.vetpar.2009.01.017

SHARIF, M. et al. Seroprevalence of Toxoplasma gondii in cattle, sheep and goats slaughtered for food in Mazandaran province, Iran, during 2005. The Veterinary Journal, v. 174, n. 2, p. 422-424, 2007. PMid:16919980. http://dx.doi.org/10.1016/j.tvjl.2006.07.004

SOUZA, W. J. S. Epidemiologia da toxoplasmose: avaliaçáo sorológica de suínos e trabalhadores em abatedouros na mesorregiáo do Grande Rio de Janeiro. 1995. 143 f. Tese (Doutorado em Parasitologia Veterinária)-Universidade Federal Rural do Rio de Janeiro, Itaguaí.

SUARÉZ-ARANDA, F. et al. The prevalence and avidity of Toxoplasma gondii $\mathrm{IgG}$ antibodies in pigs from Brazil and Peru. Veterinary Parasitology, v. 91, n. 1-2, p. 23-32, 2000. 